\title{
Ion exchange properties of some new chelating resins from cresol urea formaldehyde
}

Luma T. Tuma
Tarik E. Jassim

\begin{abstract}
$\underline{\text { Abstract }}$
Terpolymers resins( o,m,p -C UF) synthesized by the condensation of o,m,p-Cresol and Urea with Formaldehyde in the presence of acid catalyst, FTIR- spectroscopy and thermogravimetric analysis were used to characterize the terpolymers. Chelating ion exchange properties of these polymers were studied for $\mathrm{Fe}^{2+}, \mathrm{Ni}^{2+}, \mathrm{Co}$ ${ }^{2+}, \mathrm{Cu}^{2+}$ and $\mathrm{Zn}^{2+}$ ions. A batch equilibrium method was employed in the study of the selectivity of metal ion uptake . the study was carried out over a wide $\mathrm{pH}$ range and shaking time.The OUF and PUF terpolymers showed highest selectivity for ions being studied.
\end{abstract}

Keywords: Terpolymers; chelating; ion exchange properties; o, p, m-cresol urea formaldehyde

\section{Introduction}

Many research works have been carried out on the preparation and characterization of urea containing terpolymers. Terpolymer is found very useful application as adhesives, high temperature flame resistant, fibers, coating materials, semiconductors, catalysis and ion exchange resins ${ }^{(\mathbf{1 - 5})}$. Ion exchange resins have attracted much interest in the resent years due to their application in waste water treatment, metal recovery and for the identification of specific metal ions ${ }^{(6,7)}$. The basic requirement for any polymeric material to be useful as ion exchange resin are: (a) it must be sufficiently hydrophilic to permit diffusion of ions through the structure at a finite and usable rate; it must contain sufficient number of accessible ion exchangeable groups which do not undergo degradation during use and, (c) the swollen material must be denser than water. Jadhao and co-worker synthesized a terpolymer resins by condensation of 2, 2'. dihydroxybiphenylandurea with formaldehyde in the presence of $2 \mathrm{M}$ hydrochloric acid as a catalyst.The studied chelating ion exchange properties of this polymer for $\mathrm{Fe}^{3+}, \mathrm{Ni}^{2+}, \mathrm{Cu}^{2+}, \mathrm{Zn}^{2+}, \mathrm{Cd}^{2+}$ and $\mathrm{Pb}^{2+}$ ions. A batch equilibrium method and a wide $\mathrm{pH}$ rang equilibrium method was employed in the study of selectivity of metal ion up take. The polymer was found to show higher selectivity for $\mathrm{Fe}^{3+}, \mathrm{Ni}^{2+}, \mathrm{Cu}^{2+}$, than for $\mathrm{Zn}^{2+}, \mathrm{Cd}^{2+}$ and $\mathrm{Pb}^{2+}$ ions ${ }^{(8)}$ .A chelating ion exchange resin was synthesized by condensation of o cresol and urea with formaldehyde in the presence of acid catalyst and the ion exchangecapacity was evaluated with various metal ions $\mathrm{Fe}^{3+}, \mathrm{Co}^{2+}, \mathrm{Ni}^{2+}$, $\mathrm{Cu}^{2+}, \mathrm{Zn}^{2+}, \mathrm{Cd}^{2+}$ and $\mathrm{Pb}^{2+}$ ions ${ }^{(9)}$. Another chelating polymer synthesized from 2,4-dihydroxy acetophenon and biuret with formaldehyde in 4:1:5 molar ratio in presence of $2 \mathrm{M}$ hydrochloric acid as catalyst was also reported to havehigherselectivityforFe ${ }^{3+}$ andCu ${ }^{2+}$ ions ${ }^{(\mathbf{1 0})}$.Wasudeo and Deepti reported thesynthesisand characterization of terpolymer resins derived from o-aminophenyl, urea and formaldehyde and studied their ion- exchange properties for $\mathrm{Fe}^{3+}, \mathrm{Ni}^{2+}, \mathrm{Cu}^{2+}, \mathrm{Co}^{2+}, \mathrm{Zn}^{2+}, \mathrm{Cd}^{2+}$ and $\mathrm{Pb}^{2+}$ ions ${ }^{(11)}$. The present work report the synthesis and characterization of a terpolymer resins from o-cresol, $\mathrm{m}$-cresol and p-cresol with urea and formaldehyde. The work describes the synthesis of the resins in acidic media, characterization, thermal studies of the resins and the systematic studies of various transition metal ion exchange properties of the resins. 


\section{Materials And Methods:}

\section{1 chemicals:}

o- cresol, m-cresol, p-cresol and urea were of analytical grade . formaldehyde (37\% w/v) was received. Metal ion solutions were prepared by dissolving appropriate amount of metal nitrates in double distilled water. The other chemicals and solvents were used as received.

\subsection{Synthesis of o,m,p-CUF terpolymers}

The terpolymers o, m, p-CUF were synthesized by the condensation of o-cresol, m-cresol, p-cresol and urea with formaldehyde in the mole ratio of $1: 1: 3$, in the presence of $2 \mathrm{M} \mathrm{HCl}$ as catalyst. The mixture was heated at 120 ${ }^{0} \mathrm{C}$ for $5 \mathrm{~h}$. The contents of the flask were shaken periodically to ensure homogenous mixing. After the refluxing period was over, the contents of the flask were poured in to crushed ice with constant stirring and left over night.The separated coloured resin was filtered off and washed several times with cold water followed by hot water and methanol for removing unreacted monomers .Finally the resin was purified by dissolving in $10 \% \mathrm{NaOH}$ and reprecipitating with $1: 1(\mathrm{v} / \mathrm{v})$ conc. $\mathrm{HCl} /$ water. The resins thus obtained were washed with cold water followed by hot water and dried in vacuum at $100{ }^{\circ} \mathrm{C}$ the yield of the resins were between $70 \%$ to $73 \%{ }^{(12)}$.

2-3 characterization of the terpolymers were recorded on shimadzu (infinity-1) FTIR spectrophotometer in $\mathrm{KBR}$ pallets in the wave number region of $400-4000 \mathrm{~cm}^{-1}$ at Basrah university. The thermal analysis of the terpolymers were carried out in air atmosphere at a heating rate of $20{ }^{0} \mathrm{C}$ per minute on Perkin Elmere Thermogravimetric Analyzer at Tahran -Iran university.

\section{2-4 Analytical evaluation of the prepared resins as chelating polymers.}

The new resins were evaluated analytically by determining their selectivity for metal ions ,time required for chelation equilibrium and the $\mathrm{pH}$ working range for each metal ions.

\section{2-4-1 preparation of the standard solutions}

The standard solutions were prepared by dilution of standard stock solutions of $1000 \mathrm{ppm}$ metal ion prepared from metal nitrate supplied by Merckand Fluka companies using deionized water in all preparations.

\section{2-4-2 The analytical methods and measurements:}

The batch method was used in this study, thus $0.1 \mathrm{gm}$ of the resin was treated with metal ion solutions of concentration $100 \mathrm{ppm}$ and volume $10 \mathrm{ml}$ at $\mathrm{pH}$ range of (1-10) depending on the studied ion and its critical $\mathrm{pH}$ beyond which precipitation start to appear.The measurement includes also the effect of treatment time which ranged between $15 \mathrm{~min}$ to $24 \mathrm{hrs}$. the samples treatment was carried out in an orbital shaker at speed of $200 \mathrm{rpm}$ then the solutions were filtered, the concentration of the un combined metal ion remaining in the filtrate was determined by using flame atomic absorption spectrophotometer ( Py instrument AA500)the loading capacity of the resin represent the difference between the concentration of the metal ions before and after treatment from relation

\section{L.C = V (Co-Ce $) / \mathbf{m}$}

Were; L.C is the equilibrium loading capacity $(\mathrm{mg} / \mathrm{gm}), \mathrm{V}$ is the volume of solution $(\mathrm{L}), \mathrm{m}$ is the weight of the resin $(\mathrm{g}), \mathrm{Co}=$ initial concentration of Metal ion solution, $\mathrm{Ce}=$ concentration of the Metal ion solution after treatment with the resin ${ }^{(13)}$.

\section{2-4-3 Regeneration of the loaded resins}

The regeneration and the recovery of chelated metal ions were determined by treating $0.1 \mathrm{gm}$ of the loaded resin with $10 \mathrm{ml}$ of $3 \mathrm{~N} \mathrm{HCl}$ solution as an eluent for different time periods, metal ion concentration in the eluent was determined after treatment and the percentage ion recovery was plotted as function of time.

\section{Results And Discussion}

The terpolymer resins were dark brown in colour, insoluble in commonly used organic solvents, but were soluble in dimethylformamide, dimethylsulfoxide, and tetrahydrofuran. 


\subsection{Infrared spectra}

The FTIR spectrum of all terpolymer resins are presented in Figure 1 and FTIR spectral data are shown in table 1. The IR spectra revealed that all these terpolymers give rise to nearly similar pattern spectra (table 1).Abroad band appear in the region 3350-3354 $\mathrm{cm}^{-1}$ may be assigned to the stretching vibration of the phenolic hydroxyl groups exhibiting intermolecular hydrogen bonding ${ }^{(14)}$. A band appear in the region $2941-2966 \mathrm{~cm}^{-1}$ show the presence of methylene bridge $>\mathrm{CH}_{2}$ in the polymer chain . the appearance of band in the region of 1040-1060 $\mathrm{cm}^{-1}$ attributed to the vibration of ether linkage ( $\left.-\mathrm{CH}_{2}-\mathrm{O}-\mathrm{CH}_{2}-\right)$ which form during the polymerization.

Table (1) FTIR Spectral data of terpolymer resins

\begin{tabular}{|c|c|c|c|c|c|c|}
\hline $\begin{array}{l}\text { Terpolymer } \\
\text { compound }\end{array}$ & $\begin{array}{ll}\text { O-H } & \\
\text { or } & \mathrm{N}-\mathrm{H} \\
\text { st. } & \text { vib. } \\
\mathrm{cm}^{-1} & \end{array}$ & $\begin{array}{l}\text { C-H } \\
\text { st.vib } \\
\mathrm{cm}^{-1}\end{array}$ & $\begin{array}{l}\mathrm{C}=\mathrm{C} \\
\text { st.vib } \\
\mathrm{cm}^{-1}\end{array}$ & $\begin{array}{l}\mathrm{C}-\mathrm{O} \\
\text { st.vib } \\
\mathrm{cm}^{-1}\end{array}$ & $\begin{array}{l}\text { Ar.C-H } \\
\text { Bending } \\
\mathrm{cm}^{-1}\end{array}$ & $\begin{array}{l}\text { C-O-C } \\
\text { st.vib } \\
\mathrm{cm}^{-1}\end{array}$ \\
\hline OUF & 3350 & 2964 & 1442 & 1261 & 880 & 1060 \\
\hline MUF & 3352 & 2941 & 1539 & 1261 & 748 & 1040 \\
\hline PUF & 3354 & 2966 & 1558 & 1249 & 817 & 1040 \\
\hline
\end{tabular}

\section{3-2 Thermogravimetric analysis}

The thermograms of the resin samples obtained are shown in Fig.2. The TGA data of the terpolymers are given in table 2. The thermograms of OUF showed two stages of decomposition. The first stage is observed from 185 to $400{ }^{\circ} \mathrm{C}$.And the second stage was in the temperature range of $400-710{ }^{\circ} \mathrm{C}$, while for PUF is showed three stages of decomposition and for MUF is showed two stages of decomposition.From the results obtained that the char percentage of terpolymers is from 0.837 to 7.78 due to little amount of aromatic compounds in the terpolymers lattice ,at the other hand the activation energies of these terpolymers which calculated by Arrhenius equation and char content percentage were proportional.Data reveals that the terpolymers are thermally stable.

\subsection{Analytical evaluation of terpolymer resins:}

The prepared resins were treated with the metal ions $\mathrm{Fe}^{2+}, \mathrm{Ni}^{2+}, \mathrm{Cu}^{2+}, \mathrm{Co}^{2+}$ and $\mathrm{Zn}^{2+}$ ions. The factors affecting its L.C. for these ions were evaluated.

\subsubsection{The effect of time treatment:}

The effects of treatment time on L.C. of terpolymers for metal ions were studied at different $\mathrm{pH}$. Figures (311) show the effect of shaking time on the L.C for terpolymers for the studied ions at different pH values. The L.C. presented in these figures indicates the conclusions:

1- Loading capacity increased with increasing treatment time and $\mathrm{pH}$ for the studied ions.

2- At higher $\mathrm{pH}$ values equilibrium time is shorter than at lower $\mathrm{pH}$ values.

3- Equilibrium time varies between 2 to $6 \mathrm{hrs}$.

4- The total loading capacity of terpolymers for the studied ions was in the following order:

$$
\begin{array}{ll}
\mathrm{Cu}^{2+}>\mathrm{Zn}^{2+}>\mathrm{Fe}^{2+}>\mathrm{Ni}^{2+} \sim \mathrm{Co}^{2+} & \text { for OUF terpolymer } \\
\mathrm{Zn}^{2+}>\mathrm{Fe}^{2+}>\mathrm{Cu}^{2+}>\mathrm{Ni}^{2+} \sim \mathrm{Co}^{2+} & \text { for PUF terpolymer } \\
\mathrm{Zn}^{2+}>\mathrm{Fe}^{2+}>\mathrm{Cu}^{2+}>\mathrm{Co}^{2+} \sim \mathrm{Ni}^{2+} & \text { for MUF terpolymer }
\end{array}
$$

The metal complexing nature of the terpolymers depends not only on the nature of the legand groups but also their accessibility towards metal ions . thus, steric hindrance by the polymeric matrix and hydrophobic nature of the polymer ligands can limit the chelating reaction ${ }^{(15)}$.

\subsection{2 pH effect}

Figures (12- 28) show the effect of $\mathrm{pH}$ on the loading capacity of terpolymers . the total L.C. sequence of terpolymers from studied ions at different $\mathrm{pH}$ values were as follows: 


\begin{tabular}{|c|c|}
\hline pH=2: $\mathrm{Zn}^{2+}>\mathrm{Cu}^{2+}>\mathrm{Fe}^{2+}>\mathrm{Co}^{2+} \sim \mathrm{Ni}^{2+}$ & for OUF, PUF \\
\hline $\mathrm{pH}=2: \mathrm{Zn}^{2+}>\mathrm{Fe}^{2+}>\mathrm{Co}^{2+}>\mathrm{Cu}^{2+}>\mathrm{Ni}^{2+}$ & for MUF \\
\hline $\mathrm{pH}=4: \mathrm{Fe}^{2+} \sim \mathrm{Cu}^{2+}>\mathrm{Zn}^{2+}>\mathrm{Co}^{2+} \sim \mathrm{Ni}^{2+}$ & for OUF, PUF \\
\hline $\mathrm{pH}=4: \mathrm{Zn}^{2+}>\mathrm{Fe}^{2+}>\mathrm{Co}^{2+}>\mathrm{Cu}^{2+}>\mathrm{Ni}^{2+}$ & for MUF \\
\hline $\mathrm{pH}=6 \quad \mathrm{Cu}^{2+}>\mathrm{Zn}^{2+}>\mathrm{Co}^{2+} \sim \mathrm{Ni}^{2+}$ & for OUF, PUF \\
\hline $\mathrm{pH}=6 \quad \mathrm{Zn}^{2+}>\mathrm{Cu}^{2+}>\mathrm{Co}^{2+} \sim \mathrm{Ni}^{2+}$ & for MUF \\
\hline $\mathrm{pH}=8 \quad \mathrm{Co}^{2+} \sim \mathrm{Ni}^{2+}$ & for OUF, PUF \\
\hline $\mathrm{H}=8 \mathrm{Ni}^{2+}>\mathrm{Co}^{2+}$ & for MUF \\
\hline
\end{tabular}

the obtained relationships are shown in figures( 12- 28) selective chelation of some of the studied ions can be achieved by changing the $\mathrm{pH}$ of the studied solution. It's clear that L.C. highly increases of certain $\mathrm{pH}$ range under constant treatment conditions.

\subsubsection{Regenerationoftheloadedterpolymers}

$3 \mathrm{M}$ of $\mathrm{HCl}$ was used for the regeneration of terpolymers, several factors affecting the regeneration of metal ions from loaded resins, namely treated time, concentration of the eluent and the nature of the studied ions Figure (29) shows that increasing the treatment time increases the percentage ion recovery. The amount of the recovered ions depends mostly on the nature of the ion itself.the percentage ion recovery of the studied ions was in the following order:

$$
\begin{array}{cc}
\mathrm{Zn}^{2+}>\mathrm{Cu}^{2+}>\mathrm{Fe}^{2+}>\mathrm{Co}^{2+}>\mathrm{Ni}^{2+} & \text { for OUF, PUF } \\
\mathrm{Cu}^{2+}>\mathrm{Zn}^{2+}>\mathrm{Fe}^{2+}>\mathrm{Co}^{2+}>\mathrm{Ni}^{2+} & \text { for MUF }
\end{array}
$$

\begin{tabular}{|c|c|c|c|c|c|c|c|}
\hline \multirow{2}{*}{$\begin{array}{l}\text { Resin } \\
\text { name }\end{array}$} & \multicolumn{4}{|c|}{ TG/DTG } & \multirow{2}{*}{$\overline{(\mathbf{k j} / \mathbf{m o l e})}$} & \multirow{2}{*}{$\begin{array}{l}\text { Temp. of } \\
50 \% \mathrm{Wt} \\
1055 .{ }^{\circ} \mathrm{C}\end{array}$} & \multirow{2}{*}{$\begin{array}{l}\text { Char\% } \\
\text { at } 700 \\
{ }^{\circ} \mathrm{C}\end{array}$} \\
\hline & step & $\mathrm{Ti}^{\circ} \mathrm{C}$ & $T_{0}\left(D T G_{\max }\right)^{\circ} \mathrm{C}$ & $T_{f}{ }^{\circ} \mathrm{C}$ & & & \\
\hline \multirow[t]{2}{*}{ OUF } & 1 st & 80 & $\begin{array}{l}185 \\
250 \\
335\end{array}$ & 400 & 28.165 & \multirow[b]{2}{*}{445} & \multirow[b]{2}{*}{7.7838} \\
\hline & $2^{\text {nd }}$ & 405 & $\begin{array}{l}540 \\
590\end{array}$ & 710 & 84.549 & & \\
\hline \multirow[t]{3}{*}{ PUF } & 1 st & 30 & 115 & 165 & 50.1425 & \multirow{3}{*}{385} & \multirow{3}{*}{3.194} \\
\hline & $2^{\text {nd }}$ & 170 & $\begin{array}{l}230 \\
270\end{array}$ & 330 & 75.3124 & & \\
\hline & $3 d$ & 335 & $\begin{array}{l}425 \\
520\end{array}$ & 585 & 68.9425 & & \\
\hline \multirow[t]{2}{*}{ MUF } & 1 st $^{\text {st }}$ & 35 & $\begin{array}{l}250 \\
280 \\
325\end{array}$ & 360 & 34.5739 & \multirow[t]{2}{*}{450} & \multirow[t]{2}{*}{0.837} \\
\hline & $2^{\text {nd }}$ & 365 & $\begin{array}{l}555 \\
585\end{array}$ & 620 & 80.7643 & & \\
\hline
\end{tabular}

Table (2) some thermal stability characteristics determined from TGA thermograms

\begin{tabular}{|c|c|c|c|c|c|c|}
\hline Ion & $Z \mathbf{n}^{2+}$ & $\mathrm{Cu}^{2+}$ & $F e^{2+}$ & $\mathrm{Ni}^{2+}$ & $\mathrm{Co}^{2+}$ & $\begin{array}{l}\text { Resin } \\
\text { name }\end{array}$ \\
\hline \multirow{3}{*}{$\begin{array}{l}\text { Optimum } \\
\text { L.C mg } \\
\text { ion/gm resin }\end{array}$} & 9.576 & 9.84 & 9.233 & 9.3 & 9.296 & OUF \\
\hline & 9.799 & 9.632 & 7.56 & 8.799 & 8.571 & PUF \\
\hline & 9.331 & 4.941 & 8.998 & 3.799 & 3.865 & MUF \\
\hline \multirow[t]{2}{*}{ Best pII } & 6 & 6 & 4 & 8 & 8 & OUF \\
\hline & 6 & 6 & 4 & 8 & 8 & $\begin{array}{l}\text { PUF } \\
\text { MUF }\end{array}$ \\
\hline \multirow{3}{*}{$\begin{array}{l}\% \text { ion } \\
\text { recovery }\end{array}$} & 93 & 89.5 & 86.4 & 83 & 84.6 & OUF \\
\hline & 92.6 & 91.5 & 8.8 .5 & 85 & 87.6 & PUF \\
\hline & 85.6 & 87.5 & 84 & 81.4 & 82.5 & MUF \\
\hline
\end{tabular}

Table 3 The loading capacity and recovery data of terpolymers 


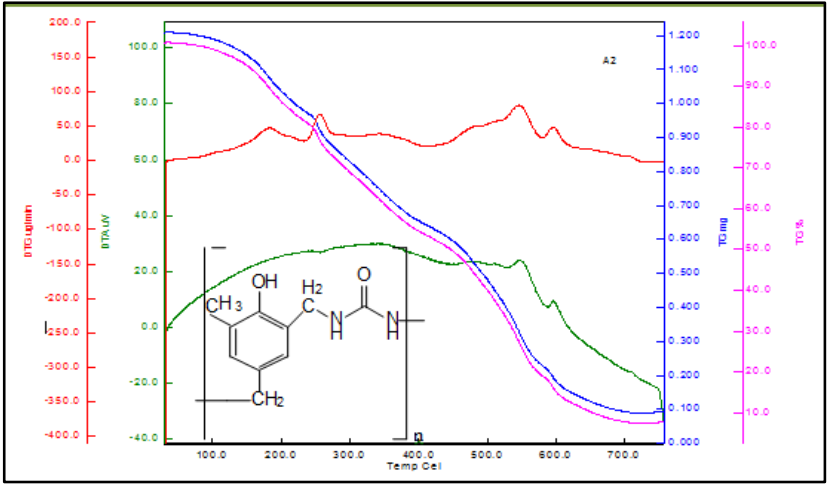

Figure 1: Typical thermogravimetric curve (DTGA) of OUF terpolymer

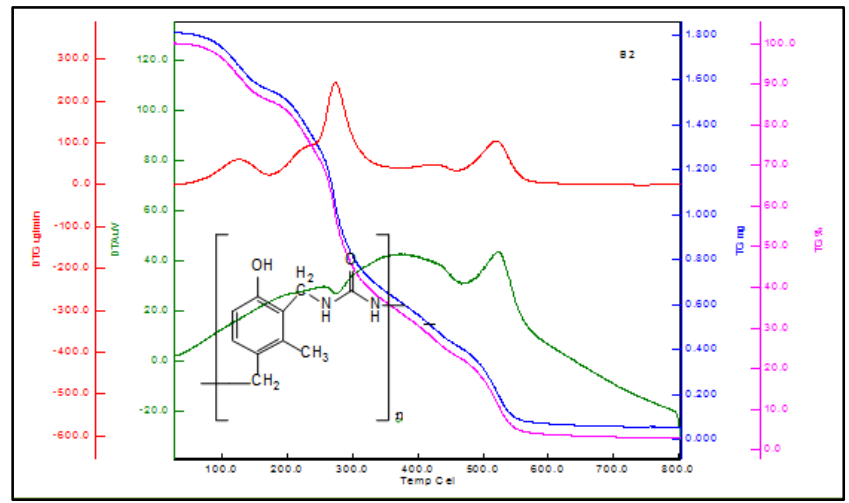

Figure 3: Typical thermogravimetric curve (DTGA) of MUF terpolymer

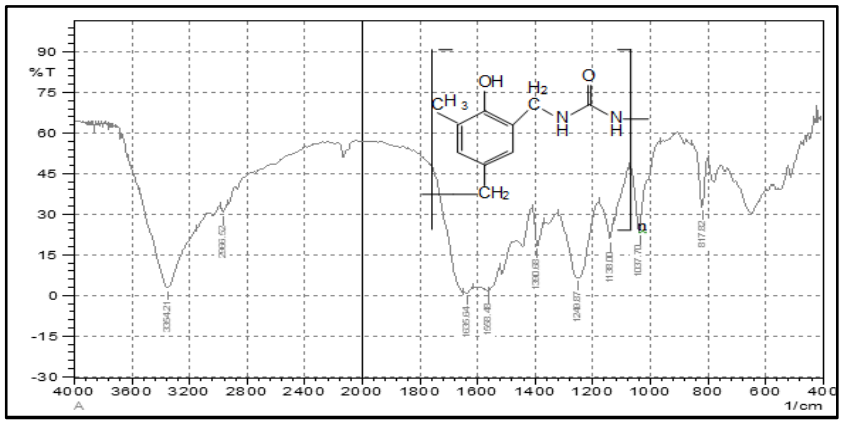

Figure 5 : typical IR Spectra of PUF terpolymer

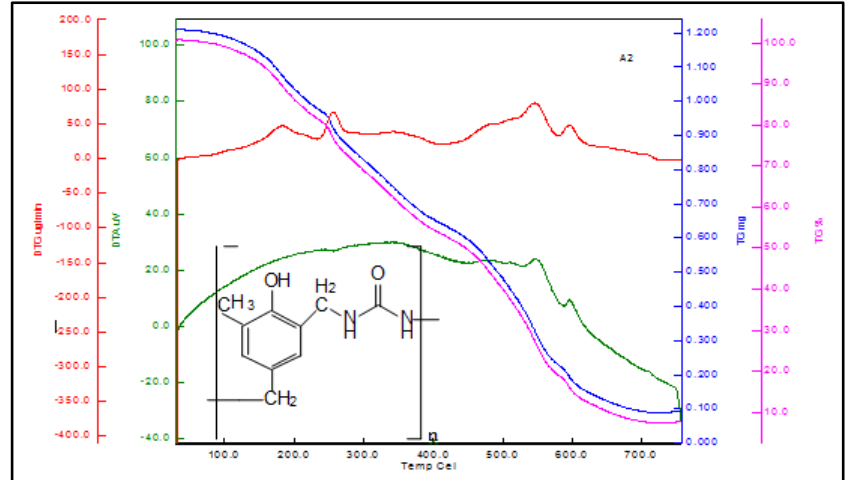

Figure 2: Typical thermogravimetric curve (DTGA) of PUF terpolymer

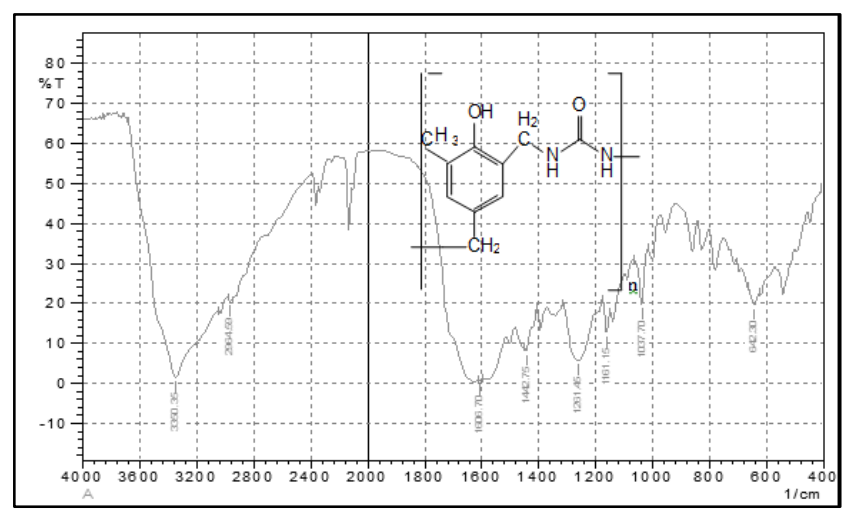

Figure 4 : typical IR Spectra of OUF terpolymer

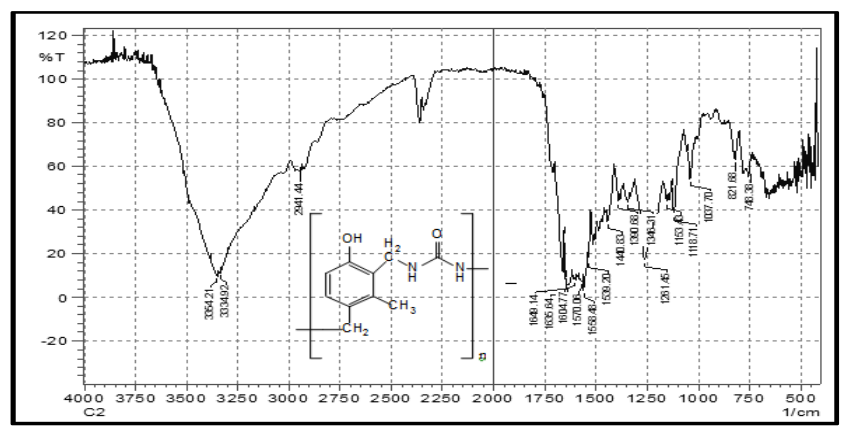

Figure 6 : typical IR Spectra of MUF terpolymer 


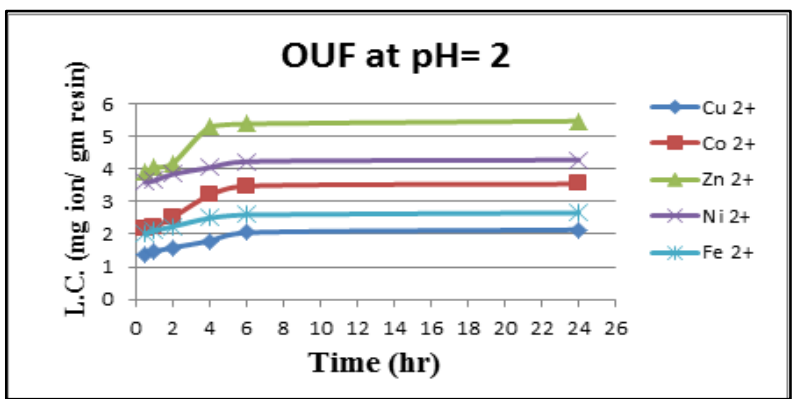

Figure 7:The effect of treatment time on the loading capacity of resin OUF towards $\mathrm{Cu}^{2+}, \mathrm{Co}^{2+}, \mathrm{Zn}^{2+}, \mathrm{Ni}^{2+}$ and $\mathrm{Fe}^{2+}$ ions at $\mathrm{pH}=2$

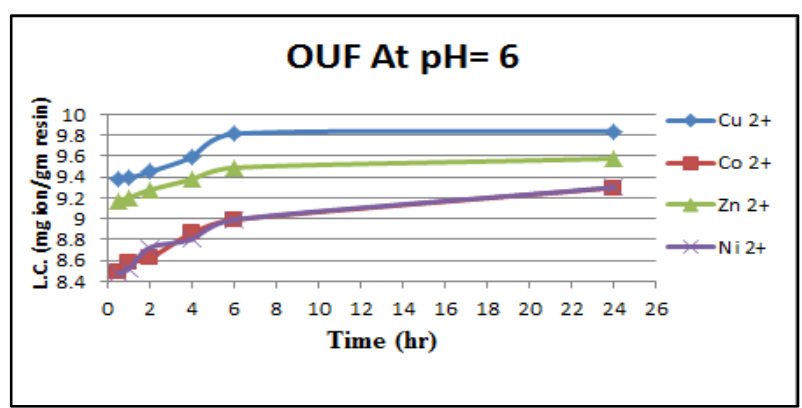

Figure 9:The effect of treatment time on the loading capacity of resin OUF towards $\mathrm{Cu}^{2+}, \mathrm{Co}^{2+}, \mathrm{Zn}^{2+}$, $\mathrm{Ni}^{2+}$ and $\mathrm{Fe}^{2+}$ ions at $\mathrm{pH}=6$

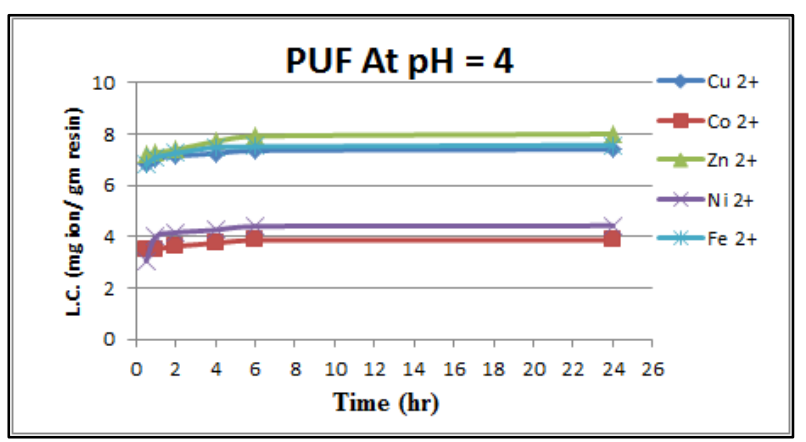

Figure 11:The effect of treatment time on the loading capacity of resin PUF towards $\mathrm{Cu} 2+$, $\mathrm{Co} 2+, \mathrm{Zn} 2+, \mathrm{Ni} 2+$ and $\mathrm{Fe} 2+$ ions at $\mathrm{pH}=4$

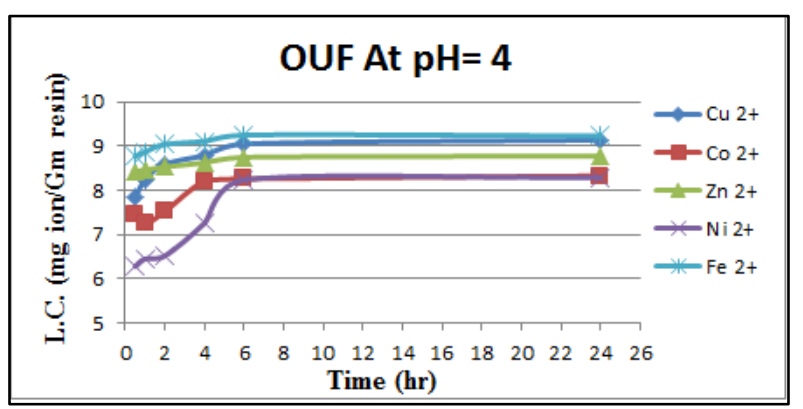

Figure 8:The effect of treatment time on the loading capacity of resin OUF towards $\mathrm{Cu}^{2+}, \mathrm{Co}^{2+}, \mathrm{Zn}^{2+}$, $\mathrm{Ni}^{2+}$ and $\mathrm{Fe}^{2+}$ ions at $\mathrm{pH}=4$

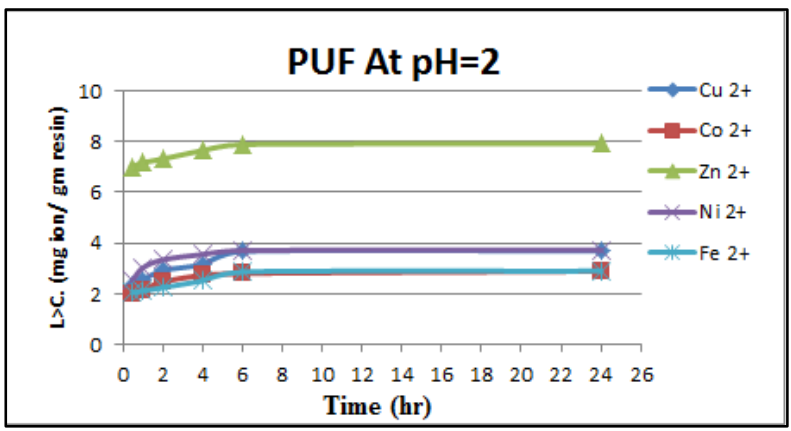

Figure 10:The effect of treatment time on the loading capacity of resin PUF towards $\mathrm{Cu} 2+$, $\mathrm{Co} 2+, \mathrm{Zn} 2+, \mathrm{Ni} 2+$ and $\mathrm{Fe} 2+$ ions at $\mathrm{pH}=2$

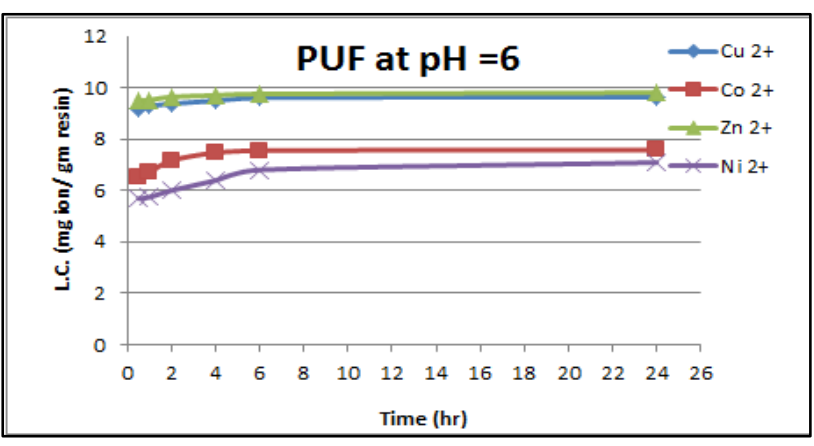

Figure 12:The effect of treatment time on the loading capacity of resin PUF towards $\mathrm{Cu}^{2+}, \mathrm{Co}^{2+}$, $\mathrm{Zn}^{2+}, \mathrm{Ni}^{2+}$ and $\mathrm{Fe}^{2+}$ ions at $\mathrm{pH}=6$ 


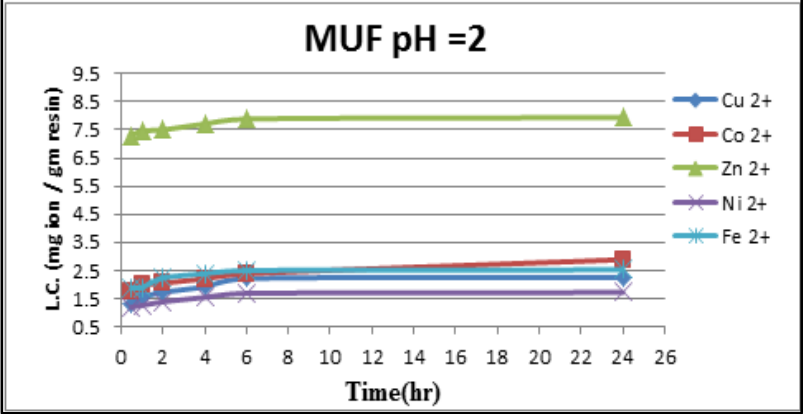

Figure 13:The effect of treatment time on the loading capacity of resin MUF towards $\mathrm{Cu} 2+, \mathrm{Co} 2+, \mathrm{Zn} 2+$, $\mathrm{Ni} 2+$ and $\mathrm{Fe} 2+$ ions at $\mathrm{pH}=2$

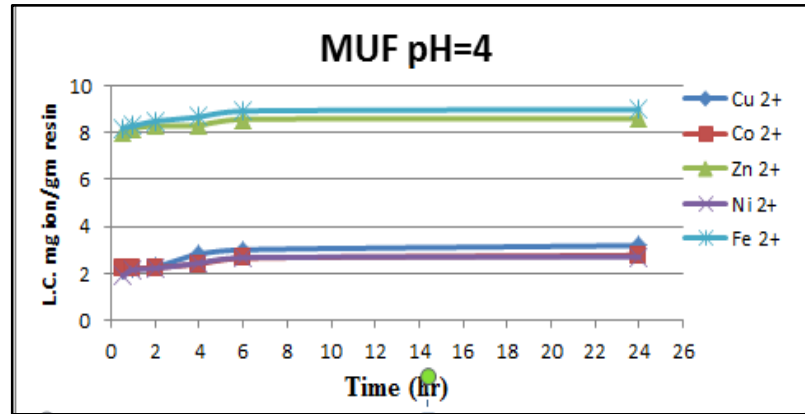

Figure 14:The effect of treatment time on the loading capacity of resin MUFtowards $\mathrm{Cu} 2+, \mathrm{Co} 2+, \mathrm{Zn} 2+$, $\mathrm{Ni} 2+$ and $\mathrm{Fe} 2+$ ions at $\mathrm{pH}=4$

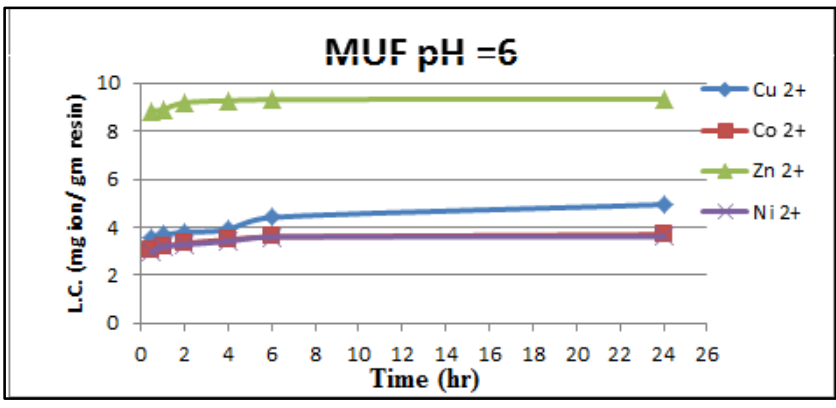

Figure 15:The effect of treatment time on the loading capacity of resin MUF towards $\mathrm{Cu}^{2+}, \mathrm{Co}^{2+}, \mathrm{Zn}^{2+}$, $\mathrm{Ni}^{2+}$ and $\mathrm{Fe}^{2+}$ ions at $\mathrm{pH}=6$

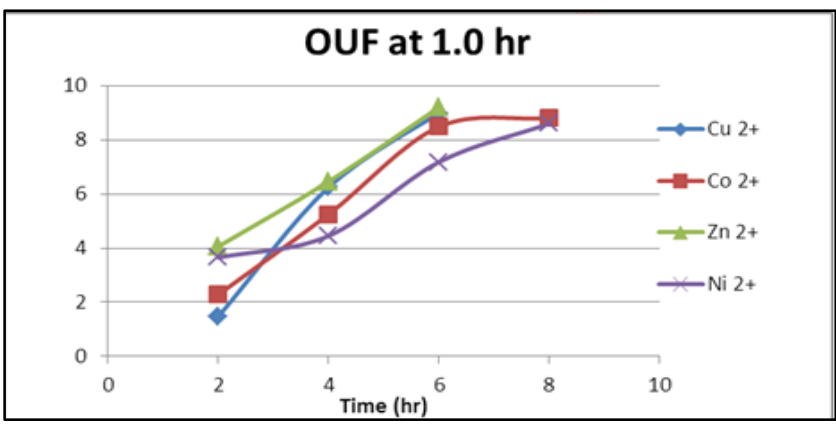

Figure 17: pH effect on total loading capacity of resin OUF towards $\mathrm{Cu}^{2+,} \mathrm{Co}^{2+,} \mathrm{Zn}^{2+}$ and $\mathrm{Ni}^{2+}$ ions at $1.0 \mathrm{hr}$

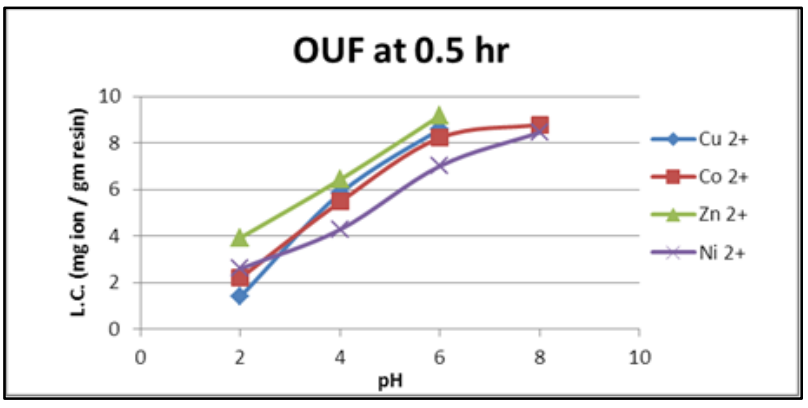

Figure 16: $\mathrm{pH}$ effect on total loading capacity of resin OUF towards $\mathrm{Cu} 2+, \mathrm{Co} 2+, \mathrm{Zn} 2+$ and $\mathrm{Ni} 2+$ ions at $0.5 \mathrm{hr}$

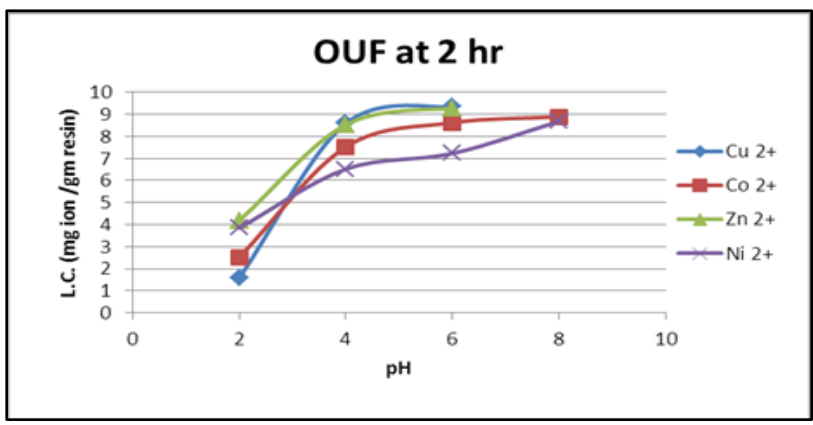

Figure 18: $\mathrm{pH}$ effect on total loading capacity of resin OUF towards $\mathrm{Cu}^{2+,} \mathrm{Co}^{2+,} \mathrm{Zn}^{2+}$ and $\mathrm{Ni}^{2+}$ ions at $2.0 \mathrm{hr}$ 


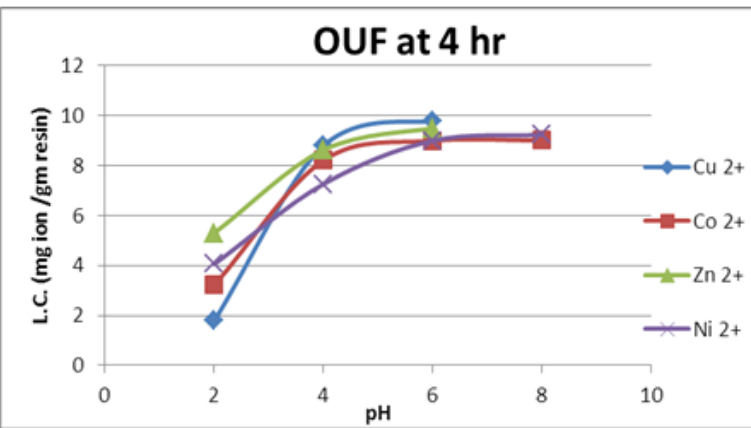

Figure 19: $\mathrm{pH}$ effect on total loading capacity of resin OUF towards $\mathrm{Cu}^{2+,} \mathrm{Co}^{2+,} \mathrm{Zn}^{2+}$ and $\mathrm{Ni}^{2+}$ ions at $4.0 \mathrm{hr}$

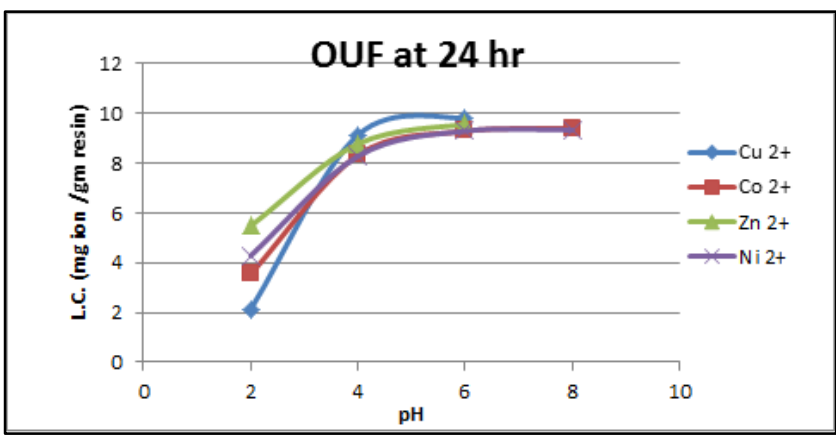

Figure 21: $\mathrm{pH}$ effect on total loading capacity of resin OUF towards $\mathrm{Cu} 2+, \mathrm{Co} 2+, \mathrm{Zn} 2+$ and $\mathrm{Ni} 2+$ ions at 24 $\mathrm{hr}$

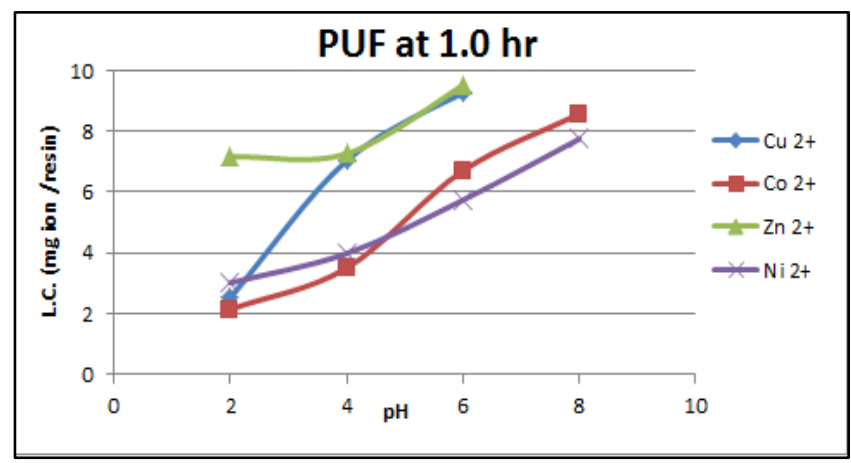

Figure 23: $\mathrm{pH}$ effect on total loading capacity of resin PUF towards $\mathrm{Cu} 2+, \mathrm{Co} 2+, \mathrm{Zn} 2+$ and $\mathrm{Ni2}+$ ions at time $=1.0 \mathrm{hr}$

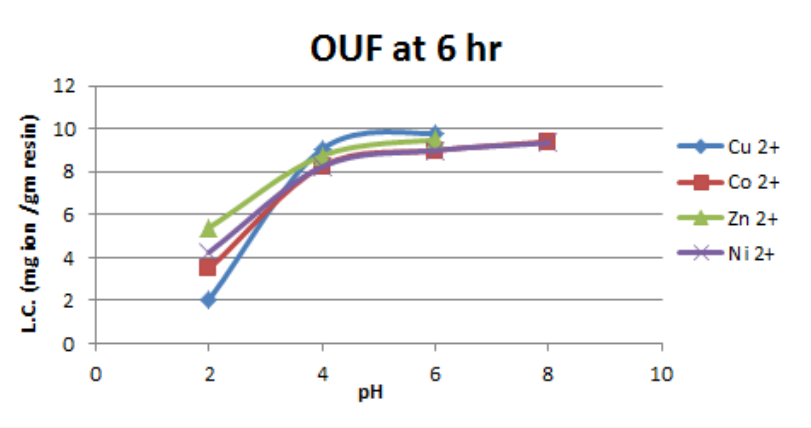

Figure 20: $\mathrm{pH}$ effect on total loading capacity of resin OUF towards $\mathrm{Cu}^{2+,} \mathrm{Co}^{2+,} \mathrm{Zn}^{2+}$ and $\mathrm{Ni}^{2+}$ ions at $6.0 \mathrm{hr}$

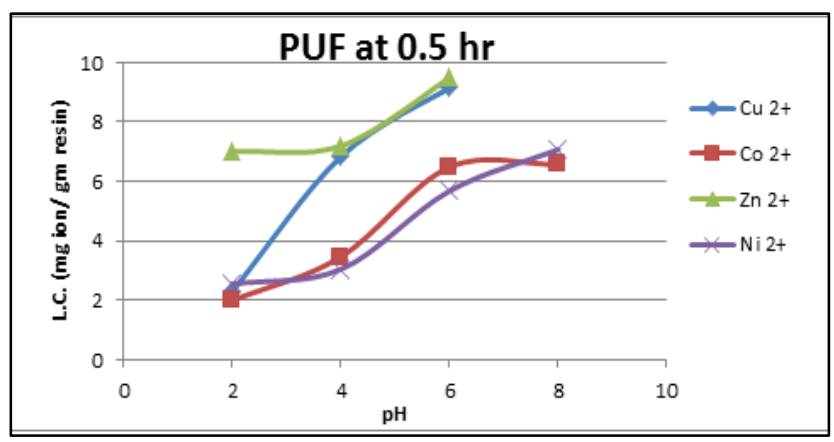

Figure 22: $\mathrm{pH}$ effect on total loading capacity of resin PUF towards $\mathrm{Cu} 2+, \mathrm{Co} 2+, \mathrm{Zn} 2+$ and $\mathrm{Ni} 2+$ ions at time $=0.5 \mathrm{hr}$

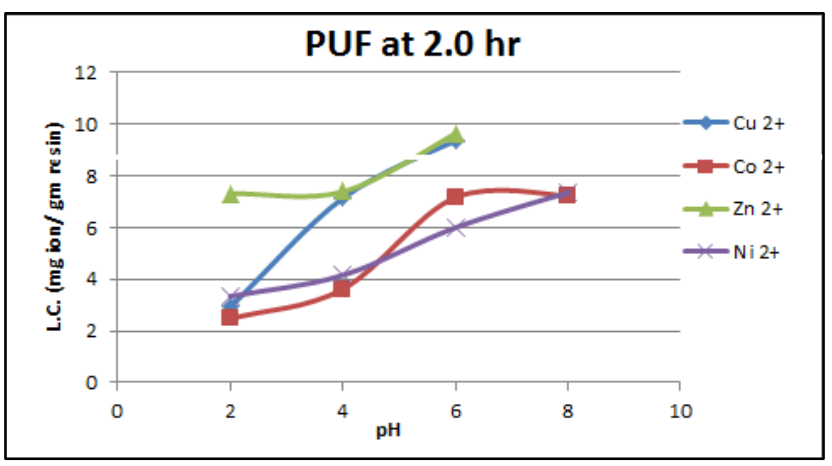

Figure 24: $\mathrm{pH}$ effect on total loading capacity of resin PUF towards $\mathrm{Cu} 2+, \mathrm{Co} 2+, \mathrm{Zn} 2+$ and $\mathrm{Ni} 2+$ ions at time $=2.0 \mathrm{hr}$ 


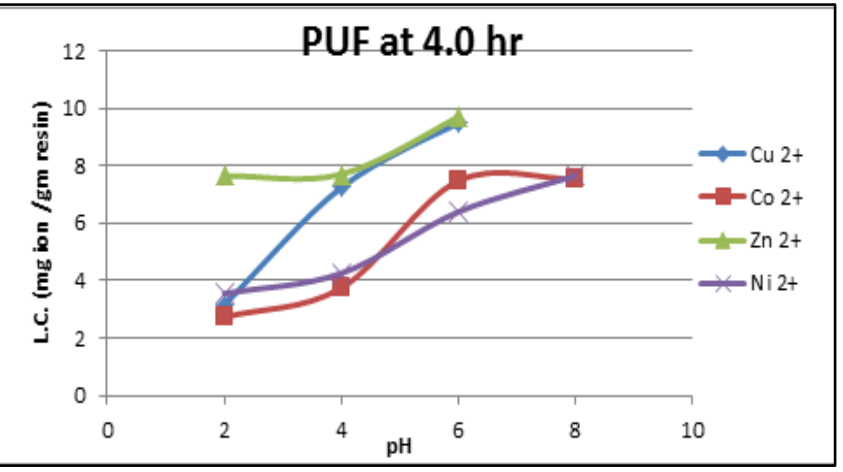

Figure 25: $\mathrm{pH}$ effect on total loading capacity of resin PUF towards $\mathrm{Cu}^{2+}, \mathrm{Co}^{2+}, \mathrm{Zn}^{2+}$ and $\mathrm{Ni}^{2+}$ ions at time $=4.0 \mathrm{hr}$

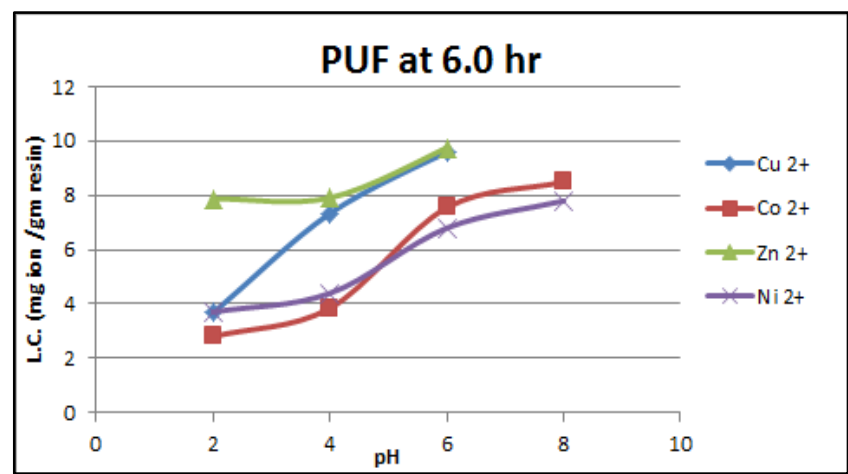

Figure 26: $\mathrm{pH}$ effect on total loading capacity of resin PUF towards $\mathrm{Cu} 2+$, $\mathrm{Co} 2+, \mathrm{Zn} 2+$ and $\mathrm{Ni} 2+$ ions at time $=6.0 \mathrm{hr}$

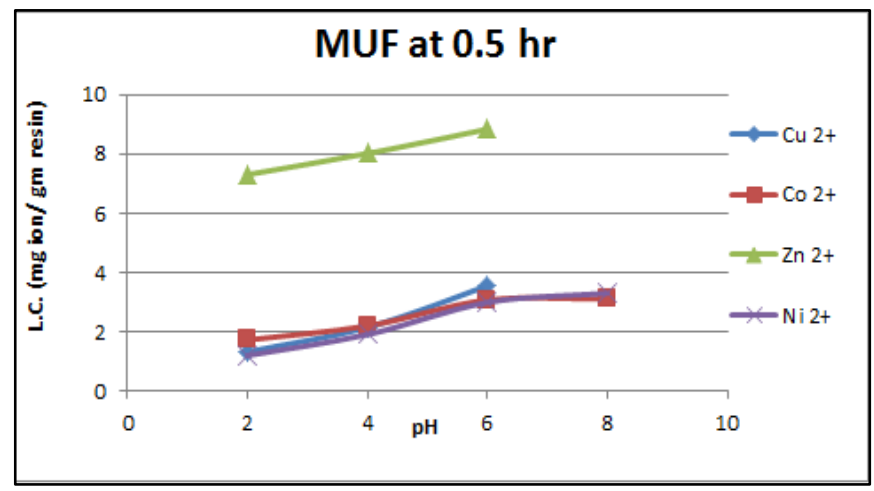

Figure 28: $\mathrm{pH}$ effect on total loading capacity of resin MUF towards $\mathrm{Cu} 2+, \mathrm{Co} 2+, \mathrm{Zn} 2+$ and $\mathrm{Ni} 2+$ ions at time $=0.5 \mathrm{hr}$

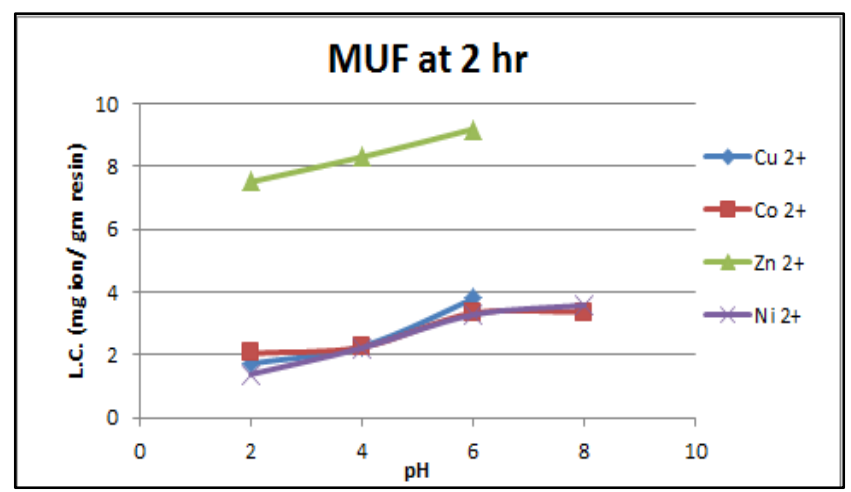

Figure 30: $\mathrm{pH}$ effect on total loading capacity of resin MUF towards $\mathrm{Cu} 2+, \mathrm{Co} 2+, \mathrm{Zn} 2+$ and $\mathrm{Ni} 2+$ ions at time $=2.0 \mathrm{hr}$

Figure 29: $\mathrm{pH}$ effect on total loading capacity of resin MUF towards $\mathrm{Cu}^{2+}, \mathrm{Co}^{2+}, \mathrm{Zn}^{2+}$ and $\mathrm{Ni}^{2+}$ ions at time $=1.0 \mathrm{hr}$

Figure 27: $\mathrm{pH}$ effect on total loading capacity of resin time $=6.0 \mathrm{hr}$

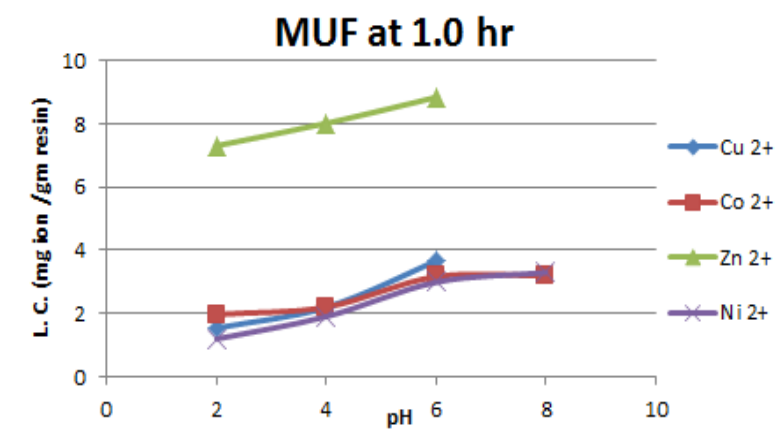

PUF towards $\mathrm{Cu} 2+, \mathrm{Co} 2+, \mathrm{Zn} 2+$ and $\mathrm{Ni} 2+$ ions at

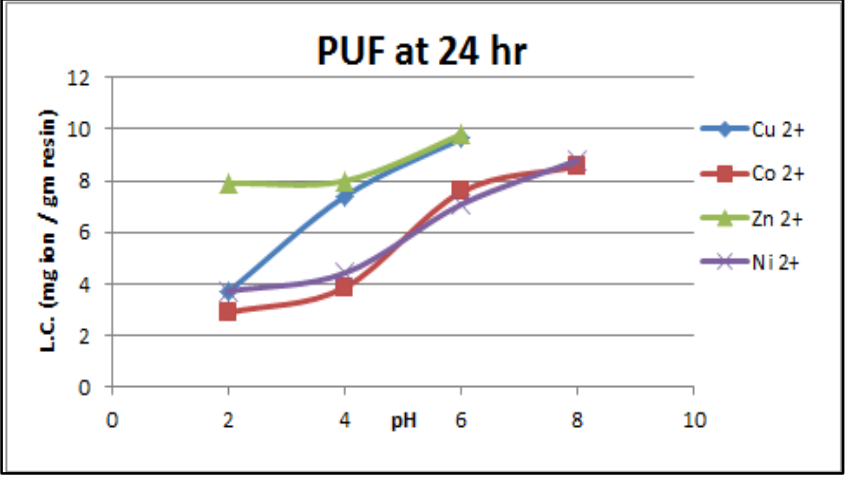




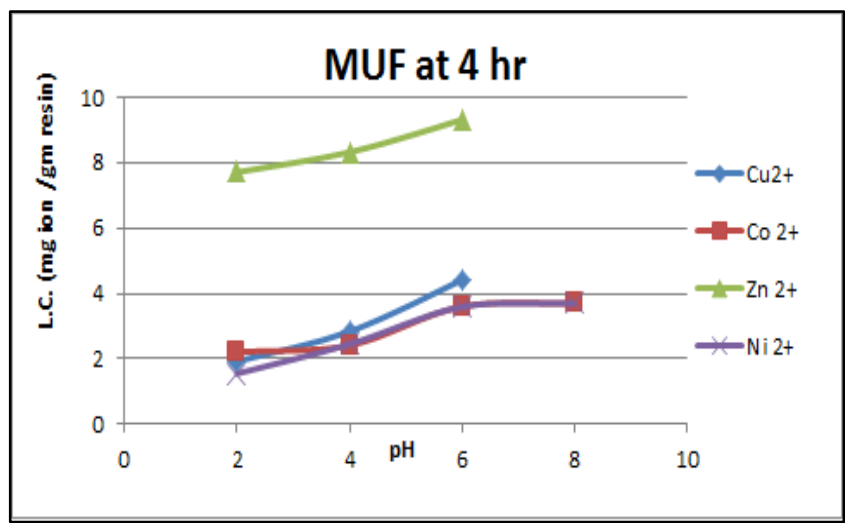

Figure 31: $\mathrm{pH}$ effect on total loading capacity of resin MUF towards $\mathrm{Cu} 2+, \mathrm{Co} 2+, \mathrm{Zn} 2+$ and $\mathrm{Ni} 2+$ ions at time $=4.0 \mathrm{hr}$

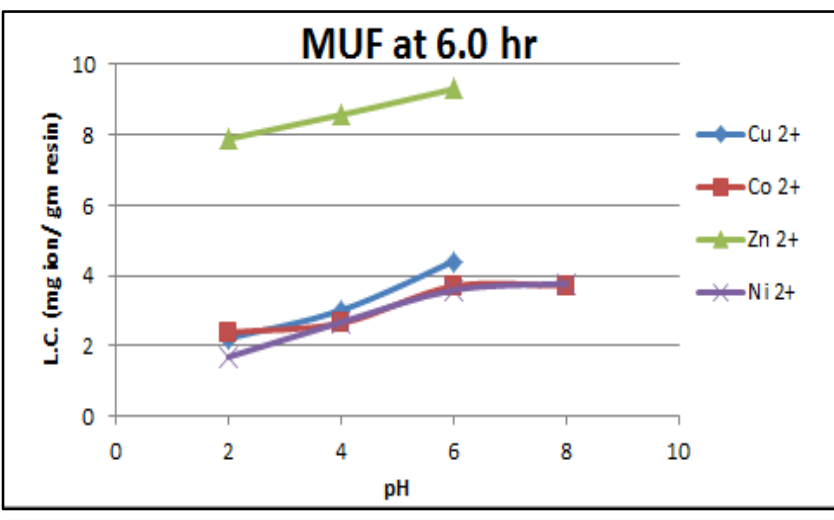

Figure 32: $\mathrm{pH}$ effect on total loading capacity of resin MUF towards $\mathrm{Cu} 2+, \mathrm{Co} 2+, \mathrm{Zn} 2+$ and $\mathrm{Ni} 2+$ ions at time $=6.0 \mathrm{hr}$

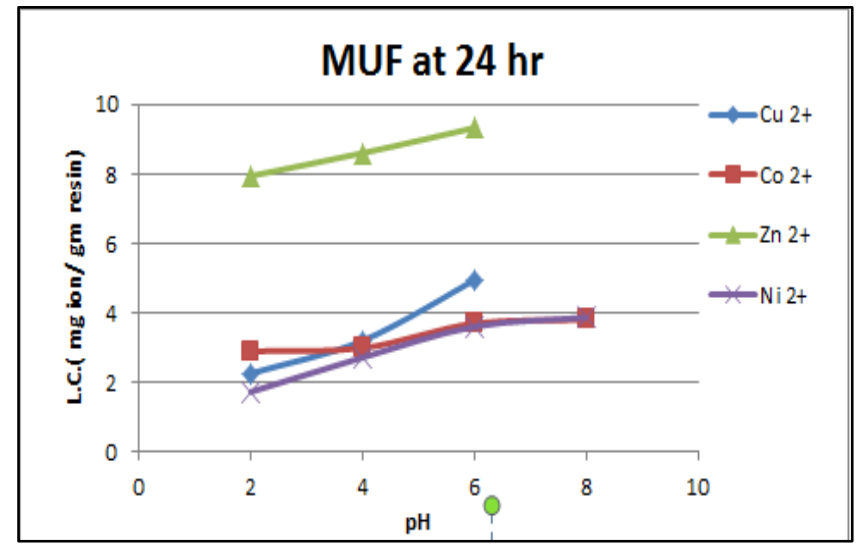

Figure 33: $\mathrm{pH}$ effect on total loading capacity of resin MUF towards $\mathrm{Cu} 2+, \mathrm{Co} 2+, \mathrm{Zn} 2+$ and $\mathrm{Ni} 2+$ ions at time $=24 \mathrm{hr}$

\section{$\underline{\text { References }}$}

1. Szabadka O, Varga E, (2003), Talanta, 59, 1081-1088.

2. Katkamwar S.S, Zadi A.B., (2009), J.App. Polyme .Sci.,113, 3330-3335.

3. Gui Li X, Rong Huang M, (2001),Chinese J. Polymer , 42, 4099-4107.

4. Wang J.Y. and Yuan C., Huaxue Yu Nianhe, 16, 20-21(2003).

5. Egorov A.N., sukhorukov Y.I., (2002), Russ. J Appl. Chem., 75,152-155.

6. Orazzhanova L.K, Yashkarova M. G., (2003),J. Appl. Poly. Sci., 87,759-764.

7. Atia A.A., Donia A.M., (2005), React. Funct. Polym., 65, 267-275 .

8. Jadhao,M.M., Paliwal L. J., (2009), Desalination 247,456-465.

9. Karunakaran M., and Magesh C. ( 2011), Arabian Journal of chemistry Vol.4, No.3, p.339-348.

10. Sanjio Kumar and Rahangdale S., (2012),J. Chem.Pharm.Res., 4 (11), p.4830-4835.

11. Wasudeo B.,Gurnule W.B., (2012),Appl. Chem., 50, 10338- 10345.

12. Gurnule W.B., (2003), Journal of applied polymer science,89,787-790.

13. Chu K. H. and Hashim M. A., (2001),Acta biotechnol., 21(4), 295-306.

14. Joshi J. D. and Patel N. B., (2006), Iran Pol. J., 15, 219-226.

15. Sankal T.R. and Kesavulu K., (2014), J. Chem. Sci., 126, 3,p.597-608. 